\title{
REVIEWS
}

Marta Tanasiewicz 1 A, E, F, Tomasz Hildebrandt ${ }^{2, \text { B-D, }}$ IZABELA OBERSZTYN ${ }^{1, B, C}$

\section{Xerostomia of Various Etiologies: A Review of the Literature}

${ }^{1}$ Department of Conservative Dentistry with Endodontics, Medical University of Silesia, Bytom, Poland

${ }^{2}$ Conservative Dentistry with Endodontics, Academic Center of Dentistry and Specialist Medicine, Bytom, Poland

A - research concept and design; $\mathbf{B}$ - collection and/or assembly of data; $\mathbf{C}$ - data analysis and interpretation;

$\mathbf{D}$ - writing the article; $\mathbf{E}$ - critical revision of the article; $\mathbf{F}$ - final approval of article

\begin{abstract}
This paper presents the etiopathogenesis, symptomatology, evaluation and treatment of mouth dryness. Xerostomia affects $1-29 \%$ of the population, mostly women. It is observed in geriatric patients and in individuals using certain medications, those subjected to radiotherapy of the head and neck region or affected with autoimmune conditions. The main signs of xerostomia include the impression of a dry mouth, problems with food ingestion and dryness of the oral mucosa and skin. Evaluation is based on structured interviews (the Fox test) and determinations of unstimulated and stimulated salivary volume. The signs of xerostomia can be attenuated with saliva substitutes, cevimeline or malic acid. Only palliative treatment of this condition is available at present. Untreated xerostomia significantly impairs the quality of life, which can potentially lead to depression (Adv Clin Exp Med 2016, 25, 1, 199-206).
\end{abstract}

Key words: xerostomia, dry mouth, etiological factors, symptoms and treatment of xerostomia.

Xerostomia (dry mouth, mouth dryness, oral dryness) is dryness of oral cavity resulting from insufficient saliva secretion or a complete lack of saliva [1]. Based on its pathogenesis, it is classified as true xerostomia (xerostomia vera, primaria), resulting from malfunction of the salivary glands, or pseudo xerostomia, also called symptomatic xerostomia (xerostomia spuria, symptomatica), in the course of which the patient has a subjective impression of oral dryness despite normal secretory function of the salivary glands.

Saliva plays a vital role in maintaining oral health. Water is the main component of saliva, constituting $99 \%$ of its volume. The other components, comprising the remaining $1 \%$, include inorganic salts of sodium, potassium, calcium and magnesium, and organic compounds, such as cholesterol, uric acid and proteins (enzymes) [1-3]. Normal secretion of saliva ranges from 0.25 to $0.35 \mathrm{~mL} / \mathrm{min}$, but can increase upon external stimulation, e.g. chewing paraffin blocks, to $1.0-3.0 \mathrm{~mL} / \mathrm{min}$ [4].

The principal functions of saliva include preparation of food for swallowing, modulation of taste, and - importantly - initial digestion by salivary amylase and maltase [5]. Equally important is the role of saliva in maintaining oral $\mathrm{pH}$ within the 6.8-7.2 range; this is achieved by a hydrogen carbonate and phosphate buffering system $[5,6]$. Other functions of saliva include moisturizing and dilution, both of which facilitate maintenance of mucosal integrity. Moreover, saliva protects the upper alimentary tract as it buffers gastric reflux at the esophageal level [3]. The antibacterial effect of saliva is also of vital importance. The presence of lactoferrin and lysozyme, which cause degradation of the peptidoglycan cell wall of Gram-positive bacteria belonging to Streptococcus spp. and Staphylococcus spp., is reflected by inhibited growth of pathogenic strains, thus, reducing the risk of caries 
and periodontal disease [2]. In view of the numerous functions played by saliva, any disorders of its secretion are reflected by an array of pathological changes, not only in the oral cavity but also within the alimentary tract [3-6].

Xerostomia affects millions patients throughout the world. Its prevalence depends on the population examined, and it varies between $12 \%$ and $30 \%[4,6]$. The results of clinical studies suggest that this problem affects mostly menopausal women [7] and individuals above 65 years of age [6]; nevertheless, xerostomia is also diagnosed in approximately $20 \%$ of 18 - to 34 -year-old individuals [4].

Depending on their nature, the causes of xerostomia can be classified as systemic or local. Based on the duration of the symptoms, the condition is qualified as persistent or periodic. Xerostomia is not a separate clinical entity, but a sign of systemic comorbidities leading to impaired functioning of the salivary glands. It accompanies hypercalcemia, vitamin deficiencies, anxiety, depression, schizophrenia, hyperthyroidism and type 1 diabetes [8]. Wangert identified several clinical states among the systemic causes of xerostomia, e.g. anxiety, neurosis and neurotic symptoms [9]. Xerostomia can be a manifestation of such conditions as Addison-Biermer anemia, Parkinson's syndrome [5], Alzheimer's disease [4], avitaminosis (B1, B2, B6 and B12), or even graft vs. host disease (GvHD) $[3,10]$.

Ivanowski et al. [12] revealed a close association between insulin-dependent diabetes and enhanced signs of mouth dryness. The authors observed a relationship between elevated salivary urea concentration and the manifestation of xerostomia in the studied subjects, which was not observed in the control group comprised of individuals without signs of xerostomia. They also documented an association between increased glucose concentration and signs of xerostomia.

Mouth dryness is frequently reported by dialyzed patients with acute or chronic renal failure. Wilczyńska-Borowska et al. [13-15] showed that alkaline pre-dialysis $\mathrm{pH}$ of the saliva (8.0) decreases on average to 7.0 within the last hour of the procedure. A highly alkaline $\mathrm{pH}$ and decreased clearance of saliva strongly influence the deterioration of oral hygiene. Disorders of saliva secretion and increased $\mathrm{pH}$ resulting from elevated urea concentrations induce rapid progression of caries, gingivitis and marginal periodontitis. Xerostomia can also manifest in individuals infected with HIV and in AIDS patients. Jeganathan et al. [15] found that the patient's age and the duration of the HIV infection determine the occurrence of mouth dryness, which in turn is reflected by higher severity of caries and overall deterioration of the quality of life. Chronic inflammation of the salivary glands is observed despite implementation of anti-retroviral therapy, radically inhibiting the secretion of saliva and increasing the dryness of the oral mucosa [17].

Chronic autoimmune conditions - rheumatoid arthritis, chronic juvenile arthritis, sarcoidosis, systemic sclerosis, and especially Sjögren's syndrome - deserve special attention in the context of xerostomia. A classic triad of symptoms predominates in the clinical manifestation of Sjögren's syndrome; aside from xerostomia, it also includes dry eye syndrome/keratoconjuntivitis sicca and polyarthritis [18]. The presence of proteins against glandular duct cells, anti-RO/SSA and anti$\mathrm{La} / \mathrm{SSB}$ antibodies and rheumatoid factor leads to the destruction of secretory vesicles with associated lymphocytic infiltration [19].

Impaired secretion of salivary proteins and peroxidase is also associated with rheumatoid arthritis. Along with immunological disorders, this is associated with the occurrence of xerostomia in rheumatoid arthritis patients [20].

Xerostomia can be also observed in Mikulicz's disease (benign lymphoepithelial lesion), which is associated with swelling of the salivary glands as a result of lymphocytic infiltration $[3,5,10,13]$.

Local factors responsible for mouth dryness include sialadenitis and sialolithiasis, acute infections of the oral cavity and pharynx (foot and mouth disease, chicken pox, herpetic stomatitis, periodontal disease), neoplasms of the mouth, pharynx and esophagus [6], and injuries to the secretory tissue of a salivary gland due to radiotherapy of head and neck malignancies [21-23]. Radiotherapy causes lysis of salivary gland cells. The extent of the injury is determined by the absorbed dose of radiation, the duration of exposure and the size of irradiated area [24]. Initial signs of xerostomia, which additionally impair the quality of life in cancer patients, are observed as early as a few days after irradiation [21]. Initially reversible dysfunction of the salivary glands develops in irradiated patients after receiving a 10 Gy dose. Irreversible impairment of salivary gland function is associated with doses ranging between 50 and 60 Gy [22, 25]. A $60 \%$ decrease in the secretion of saliva has been observed immediately after radiotherapy [21]. According to Tribius et al. [23], decreasing the dose of radiation to $<26 \mathrm{~Gy}$ in patients with planoepithelial carcinomas of the head and neck attenuated the signs of xerostomia without increasing the risk of treatment failure.

The list of internal factors that can inhibit secretion of saliva includes tobacco smoking, using complete denture prostheses, and mouth breathing due to functional impairment of the upper airways $[6,26]$. A study conducted by Al-Dwain et al. [27] involving a group of 130 users of complete 
denture prostheses confirmed the association between the occurrence of xerostomia and smoking or female patients' older age.

Xerostomia can frequently develop as an adverse effect of certain medications. According to literature, more than 500 agents cause or increase mouth dryness as a side effect $[3,5,28,29,33]$. Interactions between various drug groups also play a role in this process. Chronic pharmacotherapy can be reflected by diminished secretion of saliva or even its lack. This disorder is reversible, and resolves after the therapy is completed. A list of agents which cause drug-related xerostomia is presented in Table $1[28,29,33]$.

With time, many unfavorable changes develop as part of the physiological process of aging, including a reduced number of secretory cells within the salivary glands. This problem mainly affects menopausal women [7] and individuals older than 65 years of age. An analysis of the etiological factors of xerostomia supports the hypothesis that among older people this condition is not only an unavoidable symptom of the physiological processes of aging [18], but also a result of age-related increases in the number of medications used [29]. Research conducted at the University of Reims expanded this theory, revealing that the number ofdrugs administered is more significant than their type (especially in the case of cholinergic and xerogenic drugs) in the etiology of mouth dryness [36].

However, it should be remembered that mouth dryness is not always a symptom of true xerostomia. It is frequently a function of the overall status of the patient, resulting from fever, dehydration, cachexia, heatstroke, vomiting or diarrhea [8].
A subjective feeling of xerostomia may occur in patients taking drugs that regulate the blood pressure, antidepressants or immunosupressive drugs. The latter cause a decrease in the blood flow through the salivary glands, which may lead to reduced saliva production. This occurs quite often among patients with arterial hypertension, coronary thrombosis, diabetes and thyroid diseases at the same time, requiring the use of different drugs. The occurrence of dry mouth in this case is connected with the fact that the salivary glands have multiple types of target receptors for a variety of different drugs. The most important among them are anticholinergic drugs, which are the main cause of dry mouth. Activation of $\alpha-1 \mathrm{~A}, \beta-1, \mathrm{M} 3$ and $\mathrm{H} 2$ receptors occurs on the pathway of cAMP-dependent protein kinase $\mathrm{A}$, while NK-1 and M3R activation is induced on the protein kinase $C$ pathway. GABA and benzodiazepins cause a decrease in saliva production. Appetite-suppressing drugs may cause a feeling of dry mouth as well. An example of such a drug is sibutramine, which suppresses the reuptake of serotonin and noradrenaline. It prolongs the feeling of satiety, which causes an intensification of xerostomia [30, 33].

Sometimes xerostomia is referred to as hyposalivation; however, these two terms are not synonymous and should not be used interchangeably. Hyposalivation refers solely to decreased secretion of saliva due to external or internal influences, while xerostomia encompasses the final effect of salivary drainage, i.e. the process of its evaporation, absorption by mucosal membranes, or elimination by swallowing [3].

Decreased secretion of saliva, i.e. hyposalivation, can also result from medical mistakes

Table 1. Medications causing xerostomia [28-31]

\begin{tabular}{|l|l|}
\hline Diuretics & chlorothiazide, hydrochlorothiazide \\
\hline Antidepressants & amitriptyline, imipramine, reboxetine, bupropion hydrochloride \\
\hline Antihistaminic agents & clemastine \\
\hline Neuroleptics & derivatives of phenothiazine, butyrophenone, thioxanthene \\
\hline Bronchodilators & B2-adrenomimetics, inhalatory glucocorticoids, inhalatory cholinolytics (ipratropium) \\
\hline Anxiolytics & benzodiazepine derivatives: diazepam, oxazepam, lorazepam \\
\hline Cholinolytic agents & atropine, homatropine, scopolamine \\
\hline Hypotensive agents & angiotensin-converting enzyme inhibitors: enalapril, captopril, lysinopril, perindopril \\
\hline Opioids & morphine, codeine, methadone, pethidine \\
\hline Immunostimulants & interferon-alpha \\
\hline Appetite supressants & sibutramine \\
\hline Antimigraine drugs & rizatriptan \\
\hline
\end{tabular}


associated with stapedectomy procedures performed as part of otosclerosis management. An inadvertent injury to the tympanic cord, a branch of the facial nerve (VII) responsible for gustatory and secretory functions, leads to decreased secretion by the submandibular and sublingual glands. According to Mandel [37], in such cases a subjective impression of mouth dryness appears at rest and is associated with the decreased secretory function of the parotid glands.

\section{Clinical Manifestations of Xerostomia}

Discomfort associated with mouth dryness is the first and most common symptom reported by patients affected by xerostomia. The decreased volume of saliva impairs both the immunological and non-immunological protective barrier; depending on the severity, this can cause the following manifestations:

- problems with food ingestion, frequent consumption of fluids during meals;

- dysgeusia with a predominance of bitter and salty taste $[5,10]$;

- fetor ex ore [8];

- fissures and ruptures of the lips;

- burning of the tongue and/or lips: burning mouth syndrome (BMS) [10, 11];

- dry, pale, ruptured, and lusterless mucosal membranes;

- the presence of "milky" saliva draining from the glandular ducts [3].

Severe xerostomia can be associated with the development of cervical caries, resulting from the excessive accumulation of dental plaque at normally non-predisposed sites (the front mandibular teeth, the cusps of lateral teeth, or Black class V caries of all teeth), angular cheilitis, and candidiasis [38]. Shinozaki et al. [40] documented an association between candidiasis and mucosal disorders in patients with oral dryness. They isolated such fungi as Candida albicans and Candida glabata from the tongue and angle of the mouth, respectively, in hyposalivation patients. Guobis [41] postulates an association between mouth dryness and colonization with microorganisms, not only Candida albicans but also Lactobacillus spp.

Untreated xerostomia leads to many unfavorable changes in the oral cavity, e.g. sulcation of the tongue and atrophy of the lingual papillae [5]. Moreover, patients suffering from deficits or a lack of saliva experience problems with using complete denture prostheses. Poor retention and displacement of the prosthesis from its location lead to mucosal injury with resultant ulceration [42].

\section{Evaluating Xerostomia}

A questionnaire developed by Fox et al. [4, 27] is most commonly used to take the medical history of patients suspected of xerostomia (Table 2).

Upon documenting the presence of these symptoms, standard sialometric tests are required. The basic tests include determination of stimulated salivary flow rate (s-SFR), unstimulated salivary flow rate (u-SFR), palatal secretion (PAL) and parotid secretion (PAR). These measurements constitute the simplest methods of evaluating the secretory function of the salivary glands. Very low unstimulated and stimulated salivary flow rates are defined as $<0.1 \mathrm{~mL} / \mathrm{min}$ and $<0.7 \mathrm{~mL} / \mathrm{min}$, respectively. These values are confirmatory of xerostomia if they co-exist with symptoms specific for this condition [34]. It is important to determine both the stimulated and unstimulated volume of

Table 2. Protocol of the structured interview recommended in cases suspected of xerostomia by Fox et al. [4, 27]

\begin{tabular}{|c|l|}
\hline 1. & Do you experience mouth dryness during the night or upon waking up? \\
\hline 2. & Do you experience mouth dryness during the day? \\
\hline 3. & Do you keep a glass of water next to your bed? \\
\hline 4. & Do you drink fluids while swallowing dry foods? \\
\hline 5. & Do you experience mouth dryness during meals? \\
\hline 6. & Do you experience problems with swallowing foods? \\
\hline 7. & Do you use chewing gum on a daily basis to eliminate a feeling of mouth dryness? \\
\hline 8. & Do you use hard fruit or mint candies on a daily basis to eliminate a feeling of mouth dryness? \\
\hline 9. & Do you perceive the volume of saliva in your mouth as too small/excessive, or do you just not notice it? \\
\hline 10. & Do you need to moisten your mouth frequently? \\
\hline
\end{tabular}


saliva, as salivary secretion at rest can be decreased despite a normal volume of stimulated saliva [4].

Evaluating mucosal dryness constitutes another component of the examination. For this purpose, the modified Schirmer test (also used in ophthalmology), as well as wafer or mirror tests, can be used. The results of the latter test are presented in a three-item scale:

- I: a lack of resistance during the passing of a dental mirror along the oral mucosa,

- II: weak resistance,

- III: considerable resistance during an attempt to pass the mirror [43].

In some cases, the evaluation is augmented with a biochemical analysis of saliva, sialography, scintigraphy with technetium- $99 \mathrm{~m} \quad\left({ }^{99 \mathrm{~m} T \mathrm{c})}\right)$, CT scans or magnetic resonance imaging of the salivary glands [44].

\section{Treatment of Xerostomia}

Education of the patient, aimed at the implementation of systematic and proper oral hygiene, is a priority in the prevention and treatment of mouth dryness, and is reflected by excellent therapeutic outcomes. Avoidance of dry, acidic and salty foods is recommended, as is the elimination of stimulants, especially tobacco and alcohol [38].

Upon establishing the etiology of the condition, withdrawing certain groups of medications or eliminating their interactions, xerostomia therapy focuses on the prevention of candidiasis and ulceration of periodontal and soft tissues. It must be mentioned that antibiotics and antifungal agents cause only temporary improvements, as all xerostomia-related infections tend to recur [2, 3]. According to globally accepted guidelines, the treatment of xerostomia should be symptomatic. Therefore, in order to improve xerostomia patients' quality of life, various forms of substitutes for saliva have been introduced: gels (Biotene), aerosols (Glandosome spray), lozenges (Saliva Orthana lozenges), oral rinses and chewing gums [3]. Jang et al. [44] studied a group of xerostomia patients who had undergone liver resection and observed that mouth dryness was efficiently alleviated by chewing gum. Clinical xerostomia in those patients had been caused by the administration of opioid analgesics.

The route of application and duration of effect have significant impact on patient preferences regarding saliva substitutes; aerosols are especially appreciated by patients [5]. The composition of artificial saliva preparations is mostly based on water-soluble polymers: carboxymethylcellulose sodium salt or glycerol [45]. They also contain a mixture of ions and compounds with buffering properties. Aromas, e.g. mint, are also added to improve the smell of saliva substitutes. Preparations containing inorganic compounds - e.g., sodium fluoride, which enhances mineralization of the enamel - are recommended for patients with severe cervical caries. Herbal rinses (linseed, hollyhock flower or common marshmallow) are also successfully used in the symptomatic treatment of oral dryness [3, 5, 7, 10, 38, 39]. Jackiewicz-Barańska et al. [45] examined available preparations and concluded that none of the commercial products are ideal substitutes for human saliva, as none of them contain digestive and bactericidal enzymes or other naturally occurring proteins.

Amifostine has been found to be useful in the prevention of xerostomia in patients subjected to radiotherapy. It exerts a broad cytoprotective effect on all normal tissues by protecting them against the destruction of DNA by generating free radical scavengers and providing hydrogen ions for the repair of injured molecules. The selective protection of normal tissues is possible due to the associated higher concentration of free thiol as compared to neoplastic tissue. The efficacy of amifostine treatment varies considerably from very high effectiveness to a placebo effect depending on the clinical status of the particular patient. Adverse effects of this agent include hypotension and vomiting [46]. Pilocarpine hydrochloride in $2.5-10 \mathrm{mg}$ dose can improve salivary flow in irradiated patients [29]; however, its application is limited to certain cases only [32].

A novel technique is the use of acupuncture in the management of xerostomia associated with irradiation of head and neck malignancies. According to Simcock et al., marked alleviation of dryness can be observed as early as after eight acupuncture sessions. The acupuncture-treated group showed improvement when compared to the controls, in whom education regarding oral hygiene was the only form of intervention [49].

Although all the aforementioned methods attenuate the signs of hyposalivation, they do not eliminate the underlying problem, e.g. radiotherapy-induced injury to glandular tissue. Pringel postulated using stem cell therapy in such cases. According to this author, recent progress in understanding the cellular turnover of the salivary glands and identification of their stem and progenitor cells constitute a basis for the implementation of this form of therapeutic intervention [50].

Certain drugs, such as pilocarpine hydrochloride (mentioned above) induce secretion of saliva via parasympathetic influences. The allowable daily dose of $30 \mathrm{mg}$ should not be exceeded. As a cholinomimetic, pilocarpine hydrochloride (Salagan) 
has an affinity for muscarinic receptors $\mathrm{M} 1$ to $\mathrm{M} 3$, which leads to increased secretion in all peripheral tissues. Pilocarpine is contraindicated in patients suffering from drug-induced xerostomia associated with the intake of medications for hypertension, asthma or hyperthyroidism; in patients with narrow-angle glaucoma, angina, chronic bronchitis, nephrolithiasis or cholelithiasis; and in patients who have had myocardial infarctions [28, 29].

Cevimeline (Evoxac), which shows a high affinity for muscarinic receptors M1 and M3, is another agent used in the treatment of xerostomia. As it has a minute effect on M2 and M4 receptors in the lungs and heart, its use is not associated with such adverse events as bradycardia. Witsell et al. confirmed the efficacy of cevimeline administered in $30 \mathrm{mg}$ doses three times per day in patients irradiated with $>40 \mathrm{~Gy}$ to the head and neck region. After six weeks of treatment, the mucosal status of these patients returned to its pre-radiotherapy level [46].

Gómez-Moreno et al. [47] obtained satisfactory results using a combination of $1 \%$ malic acid with xylitol and fluorides to attenuate the signs of xerostomia in patients treated with antihypertensive agents. The dissociation of malic acid leads to the enhanced secretion of saliva due to stimulation of gustatory acid receptors. Although xylitol and fluoride ions do not modulate the secretion of saliva, they reduce the cariogenic and erosive potential of the malic acid.

\section{Conclusions}

Xerostomia is most commonly observed in patients treated with certain medications, those subjected to radiotherapy of the head and neck, or in individuals with Sjögren's syndrome. Although it mostly affects geriatric patients, xerostomia can be also observed in young individuals. This condition not only results from the physiological process of aging, but is also associated with the number and type of medications administered in the treatment of various systemic conditions. Xerostomia is also a common manifestation in menopausal women, due to estrogen deficiency. If it remains untreated, xerostomia can cause many complications, leading to nutritional deficiencies, decreased mood and finally depression. The treatment of xerostomia is long term and demanding, and as such requires a high level of patient motivation.

\section{References}

[1] Wiener RC, Wu B, Crout R, Wiener M, Plassman B, Kao E, McNeil D: Hyposalivation and xerostomia in dentate older adults. J Am Dent Assoc 2010, 141, 279-284.

[2] JA Ship: Diagnosing, managing, and preventing salivary gland disorders. Oral Diseases 2002, 2, 77-89.

[3] Guzik Ł, Kamysz E: Kserostomia - więcej niż suchość w jamie ustnej. Farmakoterapia 2009, 6, 411-414.

[4] Glore RJ, Spiteri-Staines K, Paleri V: A patient with dry mouth. Clin Otolaryngol 2009, 34, 358-363.

[5] Guzik L: Kserostomia - obraz kliniczny i terapia. Forum Med Rodz 2009, 4, 292-296.

[6] Pichór A, Doboszyńska A: Suchość jamy ustnej - niedoceniany problem kliniczny. Med Paliat Prakt 2008, 2 , 26-28.

[7] Mirzaii-Dizgah I, Agha-Hosseini F: Unstimulated whole saliva parathyroid hormone in postmenopausal women with xerostomia. J Contemp Dent Pract 2011, 12, 196-199.

[8] Busato IM, Ignácio SA, Brancher JA, Moysés ST, Azevedo-Alanis LR: Impact of clinical status and salivary conditions on xerostomia and oral health-related quality of life of adolescents with type 1 diabetes mellitus. Community Dent Oral Epidemiol 2012, 40, 62-69.

[9] Wangert B: Kserostomia. Psychosomatyka 2011, 7.1 http://psychosomatyka.110mb.com.

[10] Gurvits GE, Tan A: Burning mouth syndrome. World J Gastroenterol 2013, 19, 665-672.

[11] Mendak M, Konopka T: Nerve Conduction in Sensory and Motor Fibers of Peripheral Nerves in Burning Mouth Syndrome. Adv Clin Exp Med 2011, 6, 753-760.

[12] Ivanovski K, Naumovski V, Kostadinova M, Pesevska S, Drijanska K, Filipce V: Xerostomia and salivary levels of glucose and urea in patients with diabetes. Prilozi 2012, 33, 219-229.

[13] Cackowska-Lass A: Ocena szybkości wydzielania śliny spoczynkowej i stymulowanej u chorych z zespołem Sjogrena. Dent Med Probl 2004, 3, 469-475.

[14] Wilczyńska-Borawska MI: The effect of haemodialysis on salivary $\mathrm{pH}$ of patients with renal failure. Czas Stomat 2005, 7, 480-485.

[15] Bossola M, Tazza L: Xerostomia in patients on chronic hemodialysis. Nat Rev Nephrol 2012, 18, $176-182$.

[16] Jeganathan S, Carey H, Purnomo J: Impact of xerostomia on oral health and quality of life among adults infected with HIV-1. Spec Care Dentist 2012, 32, 130.

[17] Cavasin Filho JC, Giovani EM: Xerostomy, dental caries and periodontal disease in HIV+ patients. Braz J Infect Dis 2009, 13, 13-17.

[18] Ramos-Casals M, Brito-Zerón P, Sisó-Almirall A, Bosch X: Primary Sjögren syndrome. Praxis 2012, 28, $1565-1571$.

[19] Kobak S, Oksel F, Aksu K, Kabasakal Y: The frequency of sicca symptoms and Sjögren's syndrome in patients with systemic sclerosis. Int J Rheum Dis 2013 16, 88-92. 
[20] Zalewska A, Knaś M, Waszkiewicz N, Waszkiel D, Sierakowski S, Zwierz K: Rheumatoid arthritis patients with xerostomia have reduced production of key salivary constituents Oral Surg Oral Med Oral Pathol Oral Radiol 2013, 115, 483-490.

[21] Kakoei S, Haghdoost AA, Rad M, Mohammadalizadeh S, Pourdamghan N, Nakhaei M, Bahador M: Xerostomia after radiotherapy and its effect on quality of life in head and neck cancer patients. Arch Iran Med 2012, 15, 214-218.

[22] Perez CA Brady's: Principles and practice of radiation oncology. Lippincott Williams and Wilkins Company, $5^{\text {th }}$ ed. Philadelphia 2008, 2-137.

[23] Tribius S, Sommer J, Prosch C, Bajrovic A, Muenscher A, Blessmann M, Kruell A, Petersen C, Todorovic M, Tennstedt P: Xerostomia after radiotherapy: What matters-mean total dose or dose to each parotid gland? Strahlenther Onkol 2013, 189, 216-222. Epub 2013 Jan 27.

[24] Dirix P, Nuyts S, Van den Bogaert W: Radiation-induced xerostomia in patients with head and neck cancer. Cancer 2006, 107, 2525-2534.

[25] Jemal A, Murray T, Samuels A, Ghafoor A, Ward E, Thun MJ: Cancer statistics, 2003. CA Cancer J Clin 2003, $53,5-26$.

[26] MS Hopcraft, Tan C: Xerostomia: an update for clinicians, Austr Dent J 2010, 55, 238-244.

[27] Al-Dwairi Z, Lynch E: Xerostomia in complete denture wearers: prevalence, clinical findings and impact on oral functions. Gerodontology 2014, 31, 49-55.

[28] Buczko W: Kompendium farmakologii i toksykologii Mutschlera. Leki wpływające na układ nerwowy. Wrocław 2008, 172-178.

[29] Kostowski W, Herman ZS: Farmakologia. Podstawy Farmakologii. Wyd. 3. PZWL, Warszawa 2005, 416-423.

[30] Scully C: Drug effects on salivary glands: dry mouth. Oral Diseases 2003, 4, 165-176.

[31] Radwan-Oczko M: Topical application of drugs used in treatment of oral lichen planus lesions. Adv Clin Exp Med 2013, 6, 893-898.

[32] Aframian DJ, Helcer M, Livni D, Robinson SDM, Markitziu A, Nadler C: Pilocarpine treatment in a mixed cohort of xerostomic patients. Oral Diseases 2007, 1, 88-92.

[33] Shetty SR, Bhowmick S, Castelino R, Babu S: Drug induced xerostomia in elderly individuals: An institutional study. Contemp Clin Dent 2012, 3, 173-175.

[34] Berti-Couto Sde A, Couto-Souza PH, Jacobs R, Nackaerts O, Rubira-Bullen IR, Westphalen FH, Moysés SJ, Ignácio SA, Costa MB, Tolazzi AL: Clinical diagnosis of hyposalivation in hospitalized patients. J Appl Oral Sci 2012, 20, 157-161.

[35] Liu B, Dion MR, Jurasic MM, Gibson G, Jones JA: Xerostomia and salivary hypofunction in vulnerable elders: prevalence and etiology. Oral Surg Oral Med Oral Pathol Oral Radiol 2012, 114, 52-60.

[36] Desoutter A, Soudain-Pineau M, Munsch F, Mauprivez C, Dufour T, Coeuriot JL: Xerostomia and medication: a cross-sectional study in long-term geriatric wards. J Nutr Health Aging 2012, 16, 575-579.

[37] Mandel L: Hyposalivation after undergoing stapedectomy J Am Assoc Dent 2012, 143, 39-42.

[38] Jańczuk Z: Choroby jamy ustnej związane z zaburzeniami wydzielania śliny. W: Choroby błony śluzowej jamy ustnej i przyzębia. Podręcznik dla studentów stomatologii. Red.: Jańczuk Z, Banach J, Wyd. Lek. PZWL, Warszawa 2004, 245-252.

[39] Thelin WR, Brennan MT, Lockhart PB, Singh ML, Fox PC, Papas AS, Boucher RC: The oral mucosa as a therapeutic target for xerostomia. Oral Dis 2008, 8, 683-689.

[40] Shinozaki S, Moriyama M, Hayashida JN, Tanaka A, Maehara T, Ieda S, Nakamura S: Close association between oral Candida species and oral mucosal disorders in patients with xerostomia. Oral Dis 2012, 18, 667-672.

[41] Guobis Ž, Kareivienė V, Basevičienè N, Paipalienė P, Niedzelskienė I, Sabalys G, Kubilius R, Gervickas A: Microflora of the oral cavity in patients with xerostomia. Medicina (Kaunas) 2011, 47, 646-651.

[42] Gajowiak I: Zastosowanie preparatów adhezyjnych we współczesnej protetyce stomatologicznej. Porad Stomatol 2009, 6, 221-228.

[43] Knychalska-Karwan Z: Stomatologia Geriatryczna. Collegium Medicum UJ. Kraków 1995, 83-109.

[44] Jang SY, Ju EY, Kim DE, Kim JH, Kim YH, Son M, Jang M, Jeong JH, Kim KS: First flatus time and xerostomia associated with gum-chewing after liver resection. J Clin Nurs 2012, 21, 2188-2192.

[45] Jackiewicz-Barańska D: Sztuczna ślina. Pol J Cosmetol 2007, 10, 80-90.

[46] Dwilewicz-Trojaczek J: Amifostyna - lek cytoprotekcyjny. Współczesna Onkol 2004, 8, 101-106.

[47] Witsell DL, Stinnett S, Chambers MS: Effectiveness of cevimeline to improve oral health in patients with postradiation xerostomia. Head Neck 2012, 34, 1136-1142.

[48] Gómez-Moreno G, Guardia J, Aguilar-Salvatierra A, Cabrera-Ayala M, Maté-Sánchez de-Val JE, Calvo-Guirado JL: Effectiveness of malic acid $1 \%$ in patients with xerostomia induced by antihypertensive drugs. Med Oral Patol Oral Cir Bucal 2013, 18, 49-55.

[49] Simcock R, Fallowfield L, Monson K, Solis-Trapala I Parlour L, Langridge C, Jenkins V: ARIX: A randomised trial of acupuncture vs. oral care sessions in patients with chronic xerostomia following treatment of head and neck cancer. Ann Oncol 2013, 24, 776-783.

[50] Pringle S, van Os R, Coppes RP: Adult salivary gland stem cells and a potential therapy for xerostomia. Stem Cells 2013, 4, 613-619. 


\section{Address for correspondence:}

Tomasz Hildebrandt

Department of Conservative Dentistry with Endodontics Academic Center of Dentistry and Specialist Medicine

Plac Akademicki 17

41-902 Bytom

Poland

E-mail: hildebrandt.tomek@gmail.com

Conflict of interest: None declared

Received: 26.01.2014

Revised: 17.07.2014

Accepted: 29.10.2014 